\title{
An Ancient Maya Hafted Stone Tool from Northern Belize
}

Harry J. Shafer

Thomas R. Hester

Center for Archaeological Research

Follow this and additional works at: https://scholarworks.sfasu.edu/ita

Part of the American Material Culture Commons, Archaeological Anthropology Commons, Environmental Studies Commons, Other American Studies Commons, Other Arts and Humanities Commons, Other History of Art, Architecture, and Archaeology Commons, and the United States History Commons

Tell us how this article helped you.

This Article is brought to you for free and open access by the Center for Regional Heritage Research at SFA ScholarWorks. It has been accepted for inclusion in Index of Texas Archaeology: Open Access Gray Literature from the Lone Star State by an authorized editor of SFA ScholarWorks. For more information, please contact cdsscholarworks@sfasu.edu. 


\section{An Ancient Maya Hafted Stone Tool from Northern Belize \\ Creative Commons License \\ (c) $($ ) $(9)$}

This work is licensed under a Creative Commons Attribution-NonCommercial 4.0 International License 


\section{AN ANGIWT: MAMA

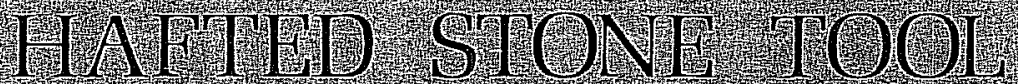 \\ HON NORHILRN BHILE}

1.1. I. I.

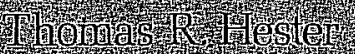
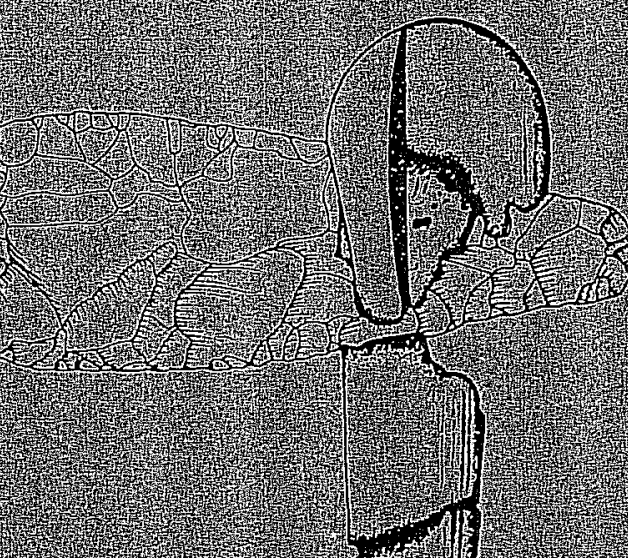

Qerter or Arehaeological heseach

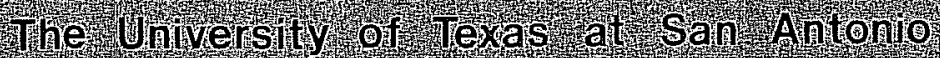

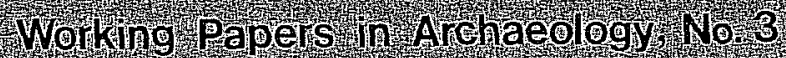

1986 



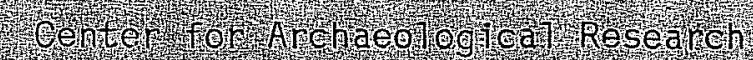

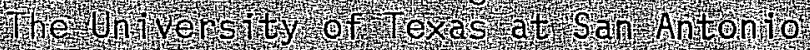

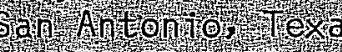

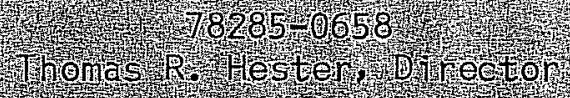

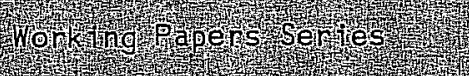

Net

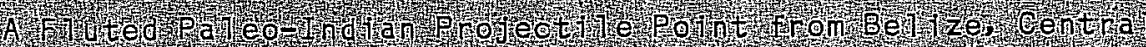

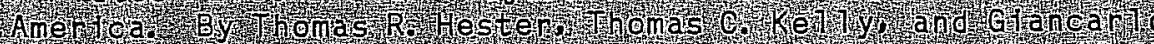

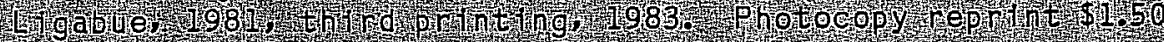

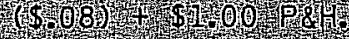

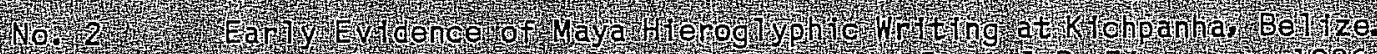

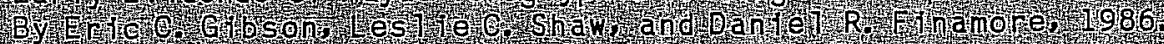
S.

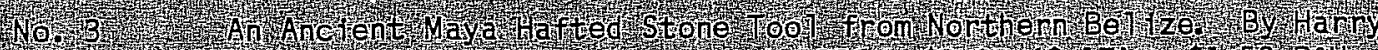

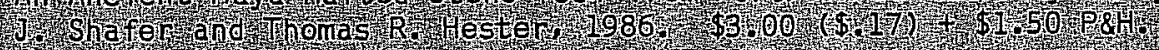

H t

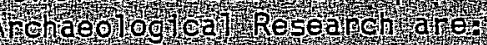

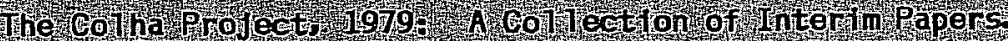

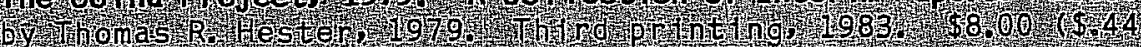
Th5 2.0.0.

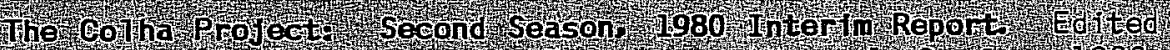
by Four that

Arebaology

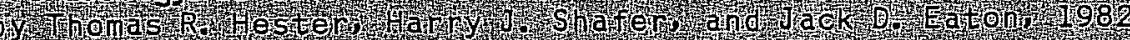
ond 1 r.

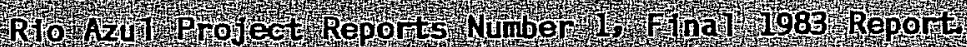

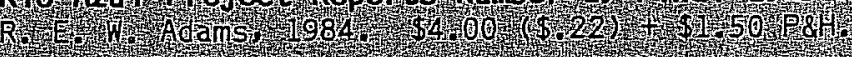

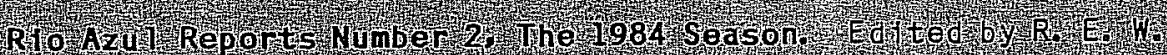

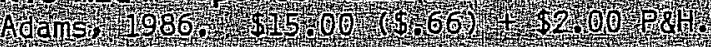

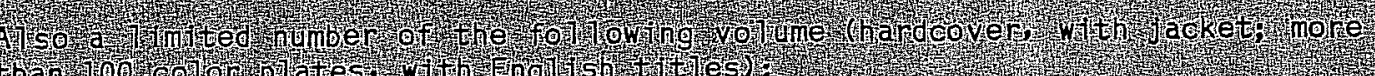
17ing 10

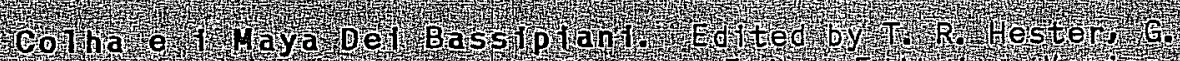

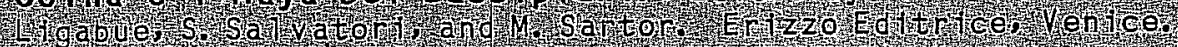
72835. 24. 

AN ANCIENT MAYA

HAFTED STONE TOOL

FROM NORTHERN BELIZE

Harry J. Shafer and Thomas R. Hester

Center for Archaeological Research

The University of Texas at San Antonio ${ }^{\otimes}$ Working Papers in Archaeology, No. 3 
A 1 ist of publications offered by the Center for Archaeological Research can be obtained by sending $\$ 1.00$ to the Center for Archaeological Research, The University of Texas at San Antonio, San Antonio, Texas 78285-0658. 
TABLE OF CONTENTS

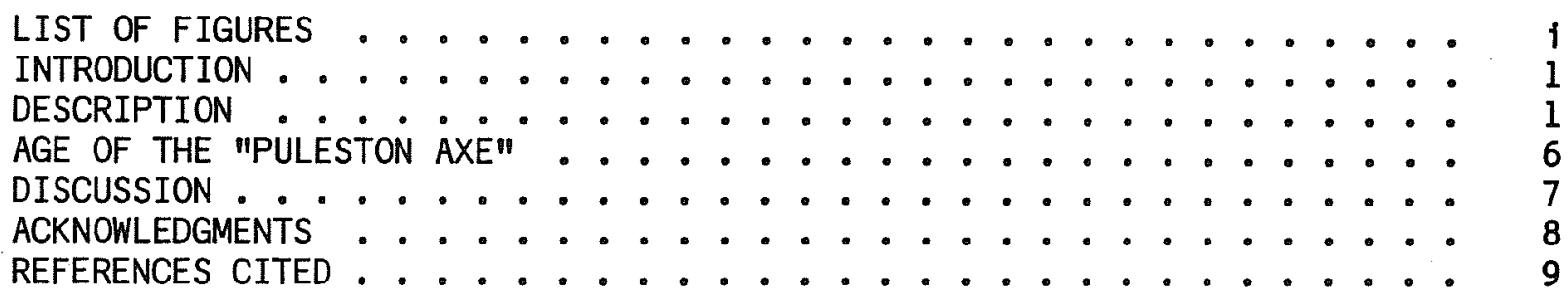

\section{LIST OF FIGURES}

1. Illustration Showing Both Sides of the Reconstructed "Puleston Axe" ....................... 2

2. Illustration Showing Both Sides of the Chert Axe Blade ...... 3

3. A Late Preclassic Oval Biface from Colha . . . . . . . . . . . 5 



\section{INTRODUCTION}

In 1974, the 1ate Dennis Puleston excavated a hafted stone artifact from the mucky fill of an ancient canal near San Antonio, Orange Walk District, in northern Belize. This specimen has never been published, although it was il Tustrated by Palacio (1976). The artifact consists of several pieces of a wooden handle and a large chipped stone biface originally set in a mortise haft through the handle.

In 1982, Mary Pohl of Florida State University, in her capacity as the director of the Rio Hondo Project, invited us to conduct a detailed study of the axe. The purpose of this paper is to provide a description of the specimen, assess its antiquity, and comment on its probable function.* It is, as best as we can te11, a unique specimen and is thus of particular significance in the study of the stone tool technology of the Low land Maya.

\section{DESCRIPTION}

An artist's detailed drawing of the reconstructed hafted axe is provided in Figure 1. In our study of the specimen, we had access to the artifact in the offices of the Department of Archaeology in Belmopan. Later, arrangements were made for the microscopic examination of the biface edges and for the possible identification of the wood used in making the handle. These facets of the study are discussed later in this paper.

In terms of basic descriptive data, we can provide the following observations. The handle or haft measures $41 \mathrm{~cm} 1$ ong, $3.4 \mathrm{~cm}$ wide at the proximal end, and $5.6 \mathrm{~cm}$ wide at the distal end. A mortise hole was carved in the distal portion of the handle, tapering outward from top to bottom. The chipped stone oval biface was set, as a blade, in this opening, with the proximal (tapered) end of the biface snuggly fitted into the mortise hole. There is no evidence of a mastic or other binding agent, although we cannot rule out the possibility that this, or perhaps some kind of fabric, was used and has simply not been preserved.

The chipped stone biface (Fig. 2) measures $22 \mathrm{~cm} 10 \mathrm{ng}, 7.3 \mathrm{~cm}$ in maximum width, and $2.0 \mathrm{~cm}$ in maximum thickness. The chert of which it is manufactured appears to be brownish hue; however, it is stained black on the surface by minerals that were in the depositional environment. We have observed similar staining on inundated cherts at Rancho Creek (Colha) and in the collections from Moho Cay near Belize City.

The biface was thinned from a large blank and was trimmed along its margins. The oval form tapers toward the proximal end which is slightly rounded and appears almost unfinished. The unfinished appearance is characteristic of

* An expanded version of this paper, with photographs of the specimen, photomicrographs of observed wear patterns, and statistical tables on oval bifaces from Colha, Belize, will appear in a book edited by Mary Poh1, slated for publication by Westview Press, Boulder, CO. 


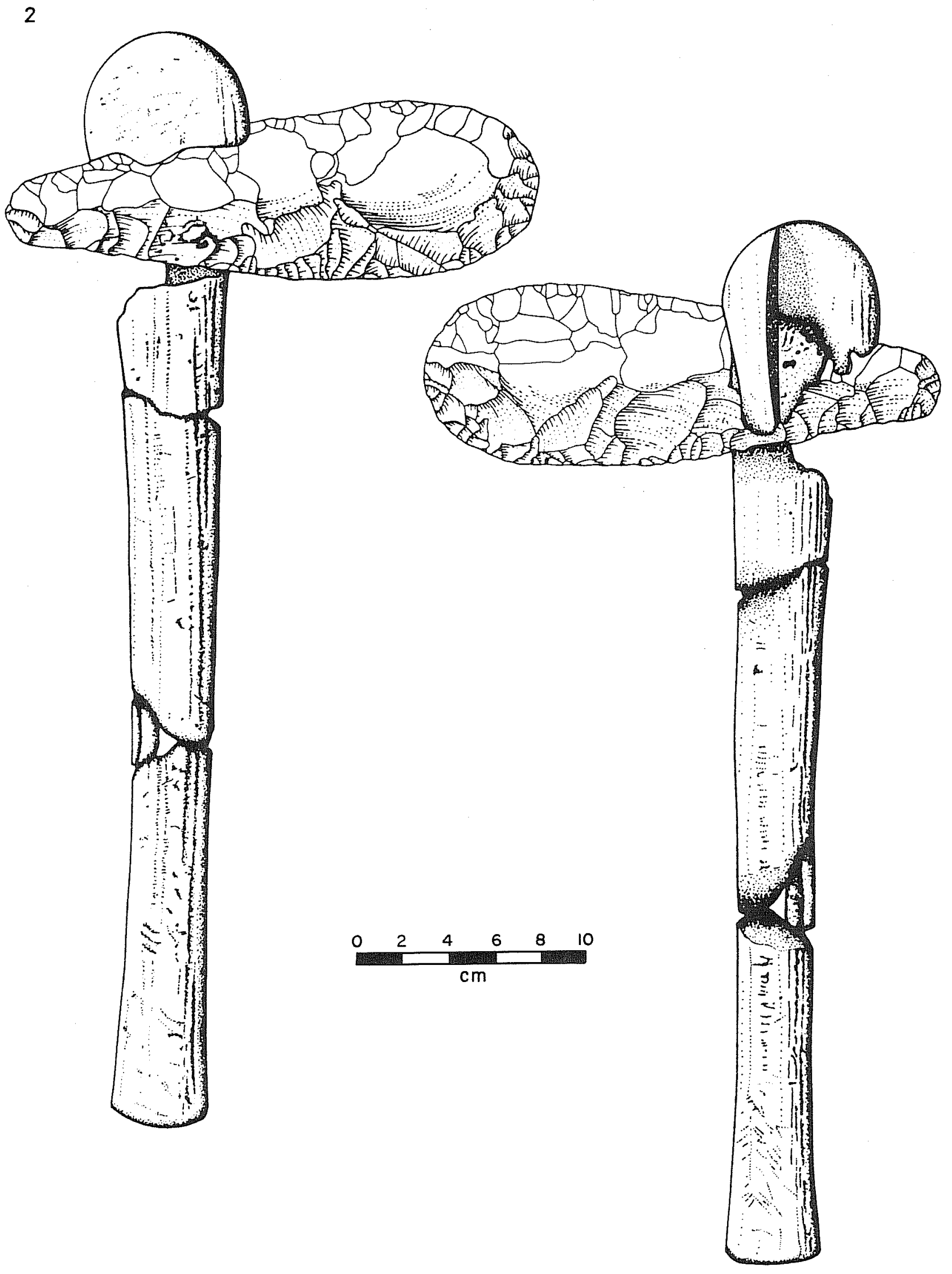

Figure 1. Illustration Showing Both Sides of the Reconstructed "Puleston Axem. Drawing by Roger Coleman. 


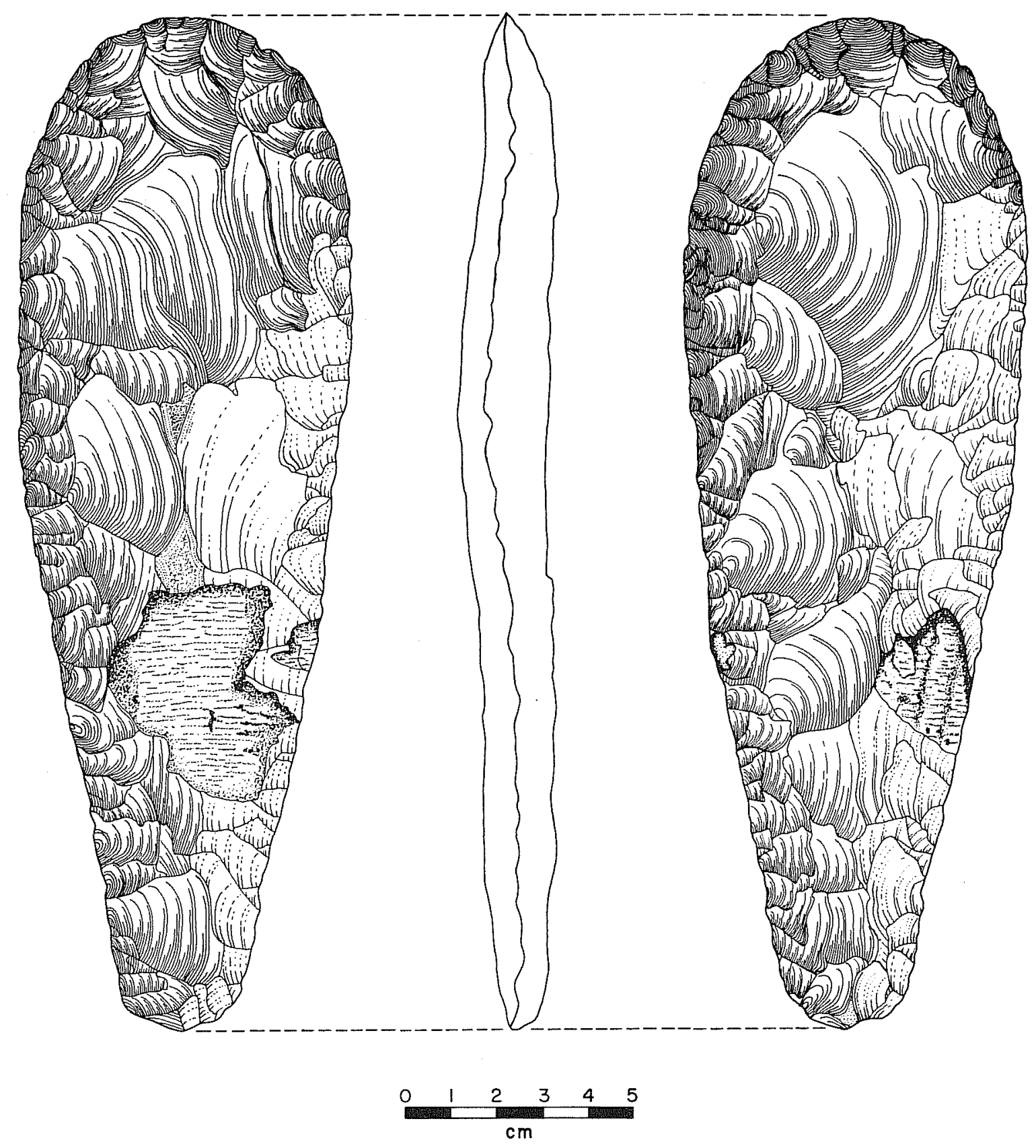

Figure 2. I1 1 ustration Showing Both Sides of the Chert Axe Blade. Drawing by Roger Coleman. 
tapered proximal ends of chert biface celts from Colha, northern Belize (Shafer 1979; Shafer and Hester 1983; see Fig. 3). The bit (distal end) is sharp, with an angle of $50-60^{\circ}$; it has been carefully retouched to maintain sharpness. The last retouch on the specimen was mainly unifacial, and the retouch scars intersected previous retouch and manufacturing flake facets. The lateral edges have been 1 ightly blunted by step-flaking, another attribute common $7 y$ seen on once-hafted biface celts in the region (Shafer et a1. 1980; Shafer 1982a).

Wear resulting from the use of the biface, once it had been set in the wooden haft, appears in the form of polish and minute striations on one side of the bit. There is a glossy polish that is clearly visible to the naked eye, but the striations or scratches that mar the polish, while detectable with the eye, are better viewed under magnification. An examination of the polish and striations was accomplished using a Wilde M5A stereomicroscope, with magnification ranges from $10 \mathrm{X}$ to $80 \mathrm{X}$.

The study of the biface edges under the microscope indicated that the gloss of the polish decreases sharply from the bit edge, being barely distinguishable $3 \mathrm{~mm}$ in from the edge. The striations are general ly oriented perpendicular to the edge but vary to an orientation that is slightly oblique. Use-motion suggested by this type of wear would clearly suggest a chopping stroke, with the angle of use varying from direct to ob 1 ique into the contact material.

The polish and striations observed on the "Puleston axe" are notably similar to use-wear patterns on exhausted oval biface celts from Colha and Kichpanha (Shafer 1982a). Interestingly, there is a distinct contrast between the high gloss and fine striations seen on this axe and the du17, mattlike polish and coarse striations recorded on specimens from Kokeal and other Pul1trouser Swamp settlements (Shafer 1983). The Pul1trouser Swamp specimens were used in a fashion that somehow brought them into contact with the soil such as in grubbing or weeding. The polish on the "Puleston axe," on the other hand, is suggestive of contact against materials containing plant silicates. In short, the use-wear on the Puleston specimen is consistent with what would be expected if the axe had been used to cut woody plants. The sharp blade does not, however, bear any evidence of direct impact point initiation fractures (Lawrence 1979) that would indicate contact with hard, rigid materials that would crush the blade edge, a trait that is seen on certain biface celts from Colha and Kichpanha.

The biface from the "Puleston axe" is virtually identical in technology and form to the Late Preclassic large oval bifaces produced in the chert workshops at Colha (Fig 3; Shafer 1979; Shafer and Oglesby 1980; Shafer and Hester 1983). Oval bifaces were made at Colha as early as the Middle Preclassic but were smaller and more crudely fashioned. Mass production of finely chipped large oval bifaces began in the Late Preclassic (Shafer and Hester 1983, 1986; Hester and Shafer 1984); oval biface technology is a 1 so present in the workshops of the Late Classic (Hester 1985). Thus, we have ample data on the manufacturing trajectories and technologies for oval biface production at Colha. We have also examined many specimens at the other end of the spectrum--exhausted axe blades, worn down by use and retouch, or, in some cases, recycled so extensively that they barely resemble their original 


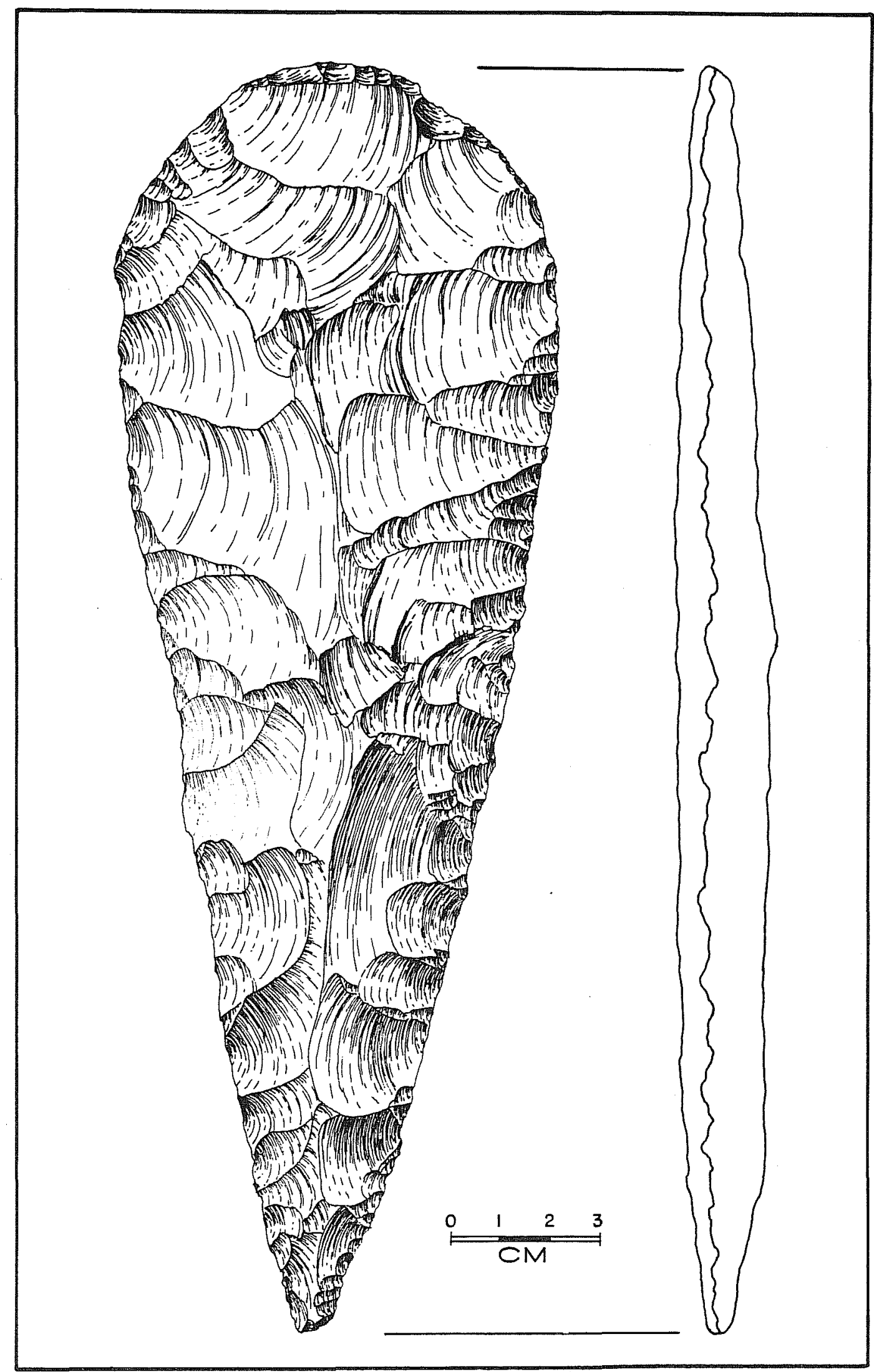

Figure 3. A Late Preclassic Oval Biface from Colha. Drawing by Kathy Roemer. 
form (Shafer 1983). Used bifaces are common in the middens and construction fill at Colha and occur in varying frequencies in the deposits of other sites in northern Belize, including Cerros (Mitchum 1982), Cuel 1o (Shafer et al. 1980; Hammond et a 1. 1979), Kokeal and other Pul1trouser Swamp sites (Shafer 1983; McAnany 1982), Kichpanha (Shafer 1982a), and E1 Pozito (Hester and Shafer ms).

\section{AGE OF THE "PULESTON AXE"}

Several 1 ines of evidence can be examined to ascertain the age of this specimen: relative stratigraphic dating, radiocarbon assays, and crossdating on the basis of form and technology of the chipped stone blade. While none of these areas of inquiry yield unequivocal results, the accumulated information clearly points to a Late Preclassic date for the specimen.

First of a11, the provenience of the artifact and the conditions in which it was discovered wi 11 be examined. It was found about two meters below the surface, in Puleston's Operation 2J, a sma11 excavation placed in an ancient Maya canal or ditch, and 1 ay near the contact of Units IIIJ2 and VII. Unit IIIJ2 was characterized as a mucky fil1, while the underlying Unit VII was an organic clay that bore evidence of agricultural activity (Bloom et a 1. 1983). Penetrating Unit VII was a hewn post. In Puleston's profiles, the axe is shown adjacent to this post which he felt was in the bottom of a canal. However, Mary Poh1 (personal communication) believes that the post was in the underlying sediments, and the axe was in the canal fil1, dating, in her opinion, to the end of the Preclassic period. The hewn post yielded a radiocarbon date of $3060 \pm 230$ B.P. (1110 B.C., uncorrected; Mary Poh 1 , personal communication). This strengthens her view that the post and the sediments in which it was contained clearly predate the axe. Additional radiocarbon dates (provided us by Poh 1) are equally inconclusive when it comes to providing a useful sequence of dates related either to the sediments or to the axe itself. However, an assay run on maize stems stratigraphically beneath the axe yie1ded a date of $2170 \pm 190$ B.P. (220 B.C., uncorrected), a closer age for the deposits in which the axe was found.

It is intriguing to note that a "tan axe," unhafted but apparently of the same oval form, was found about $1.75 \mathrm{~m}$ from the hafted specimen. This tan biface, viewed by us from a color transparency, is similar in form and technology to Late Preclassic oval bifaces at Colha. However, the material is not Colha-1ike chert but rather resembles the more colorful1y banded chert/chalcedony observed by us at Kichpanha. Puleston's original profiles place the tan biface in the same stratum, but a new interpretation of the profiles by Bloom et a1. (1983) puts it in an overlying stratum about $1.80 \mathrm{~m}$ below the surface.

Based on our research involving the form and technology of oval bifaces at Colha and elsewhere in northern Belize, it seems 1 ikely that cross-dating with morphologically similar specimens of known age is a better way of assigning an age to the "Puleston axe." As we noted earlier, oval bifaces have been manufactured at Colha since Middle Preclassic times, although the period of mass production of large oval specimens was in the Late Preclassic. While there is some overlap in form and technology from Late Preclassic into 
Late $\mathrm{Classic}$ times, the form does change rather notably from a 1 arge, broad thin biface in the Late Preclassic to a more narrow, proportionally-thicker biface.

In 1982, samples of oval bifaces were drawn from collections excavated from Late Preclassic and Late Classic workshops at Colha; attributes of 1ength, maximum width and thickness were measured taking care to include only those finished, nearly finished, or used and discarded specimens in order to arrive at those dimensions that were more closely representative of finished tools. Measurements taken on specimens from Operation 4029, a Late C1assic 1 ithic workshop deposit; Operation 2008, a Late Classic plazuela group; and Operation 2024, a Late Preclassic 1ithic workshop deposit; were subjected to discriminant analysis. The test was an attempt to distinguish between Late Preclassic and Late Classic oval biface forms. The measurements of the biface that formed part of the "Puleston axe" best fit the size range of Operation 2024, a Late Preclassic 1 ithic workshop deposit (cf. Fig. 3).

Analysis of the ceramics collected during Puleston's excavations have been conducted by Bal1 (ms.). The presence of ceramics as early as the Late Preclassic was noted by Ba 11, especial1y the types Sierra Red and Sapote Striated. These types occur throughout the Late Preclassic in northern Beljze, although at Colha, Sapote Striated appears to occur 1 ater in the period (Fred Valdez, Jr., personal communication). It is unfortunate, as Bal1 (ms.:Il) notes that the ceramics from the areas round the hewn post and the "Puleston axe" have either been lost or are "chronologically uninformative."

In sum, we assign the "Puleston axe" to the Late Preclassic, al though we do not know where it may fall within the 500-600 years of that particular era of Maya prehistory. We base this dating on Pohl's interpretation of the stratigraphy and the form and technology of the oval biface component of the axe. Available radiocarbon dates are less than satisfactory, although the date provided by the maize stems falls within the Late Preclassic period.

\section{DISCUSSION}

The discovery of a hafted chipped stone axe in an ancient Maya canal at San Antonio, Belize, has provided an important bit of information on how oval bifaces, of the sort produced in huge quantities in the chert workshops at Colha, were being hafted. A sample of wood taken from the specimen's handle was sent to Charles Miksicek of the University of Arizona for identification; no report of identification has been received at the time of this writing. The size of the handle, the mode of hafting, and presumably the identification of the wood are important attributes that can be ascertained from the "Puleston axe." While hafted axes are sometimes depicted in Classic Maya vase paintings (e.g., Coe 1973:92), in codices (as in the Codex TroCortesianus), and as 1 arge chipped monolithic axes (e.g.s, at San Jose, Thompson 1939; and Nohmu 1, Gann and Gann 1938) these do not provide specific technological details on the axes or their component parts.

The common occurrence of oval biface celts in Late Preclassic and Late Classic artifact assemblages in northern Belize--from production sites like 
Colha and from the "consumer" sites to the north and west (Shafer 1982b)-indicates that these were components of hafted axes common $1 y$ used in the regional technology. The variability and use-wear seen on the oval bifaces at Pul1trouser Swamp sites and other fragmentary specimens from the Rio Hondo raised field excavations compared to the "Puleston axe," as well as specimens examined from Colha and Kichpanha, suggest that the context of use was not always the same. While the oval bifaces would likely have been hafted in much the same manner as the "Puleston axe" (and we have observed haft wear in the form of polish and abrasion along the crests of both surfaces and 1 ateral edges near the proximal ends of Colha bifaces [Shafer ms.] which suggest the same hafting mode), the specimens from Kokeal and Pul1trouser Swamp show usewear suggestive of ground contact. The wear on the Puleston axe biface and similar wear on bifaces from other localities, for example, Kichpanha (Shafer 1982a) and Colha (Shafer ms.) are more indicative of the cutting of woody materials or plants. With the specimen found by Puleston, we have a rare, perhaps unique, opportunity of examining an ancient Maya axe in its original form and of speculating, on the basis of edge-wear and stratigraphic context, as to its possible function in clearing woody vegetation. The oval bifaces could be, once hafted, used in a variety of tasks, from the clearing of woody plants, to hoeing or grubbing, in working in and around raised fields, and at various jobs such as ditch-digging, cleaning, and weeding, crop harvesting, etc. Likely the "Puleston axe" was used in several different ways, and we are seeing, in the observable use-wear, the last way in which it was used before its owner lost or discarded it.

\section{ACKNOWLEDGMENTS}

The data presented here result from the cooperation of numerous colleagues. We are grateful to the Archaeology Department of Belize, particularly $H_{\text {. }} W$. Topsey, for permission to study the "Puleston axe" and to bring the biface to Texas A\&M University for microscopic examination and photomicrographic documentation. Mary Pohl of the Florida State University provided the invitation to study the specimen and also shared original field notes and data on associated materials. Erwin Roemer, Jr. (Texas A\&M), and Charles Suhler (UT-San Antonio) aided in acquiring comparative data on oval bifaces from Colha; David Carlson (Texas A\&M) directed the computer research on quantitative comparisons. Roger Coleman prepared the line drawings of the Puleston axe. 


\section{REFERENCES CITED}

Ba11, J.W.

m5. Report on the Ceramics of the San Antonio Locality, Albion Is 7 and, Northwestern Belize, Central America. Manuscript on file at Texas A\&M University.

Bloom, P. R., M. Poh1, C. Buttleman, F. Wiseman, A. Covich, C. Miksicek, J. Ba11, and J. Stein

1983 Prehistoric Maya Wetland Agriculture and the Alluvial Soils near San Antonio, Rio Hondo, Belize. Nature 301:417-419.

Coe, M. D.

1973 The Maya Scribe and His World. Grolier Club, New York.

Gann, T. and M. Gann

1938 Finds in Maya Mounds: Discoveries in British Honduras. I17 ustrated London News, Jan. 22:121-123.

Hammond, H., D. Pring, R. Wilk, S. Donaghey, F. P. Saut, E. S. Wing, A. V. Miller, and L. H. Feldman

1979 The Earliest Low 1 and Maya: Definition of the Swasey Phase. American Antiquity $44(1): 429-433$.

Hester, T. R.

1985 The Maya Lithic Sequence in Northern Be1 ize. In Stone Tool Analysis, Essays in Honor of Don E. Crabtree, edited by $M$. Plew, J. Woods, and M. Pavesic:187-210. University of New Mexico Press, Albuquerque.

Hester, T. R. and H. J. Shafer

1984 Exploitation of Chert Resources by the Ancient Maya of Northern Belize, Central America. World Archaeology 16(2) : 157-173.

ms. The Lithics of E1 Pozito. Manuscript in preparation; authors' files.

Lawrence, R. A.

1979 Experimental Evidence for the Significance of Attributes Used in Edge-Damage Analysis. In Lithic Use Hear Analysis, edited by B. Hayden:113-122. Academic Press, New York. 
McAnany, P. A.

1982 Settlement at Pul1trouser Swamp: Use, Breakage, and Recycling. Paper presented at Second Maya Lithic Conference, San Antonio, Texas.

Mitchum, B.

1982 Lithic Artifacts from Cerros, Belize: Production, Consumption and Trade. Paper presented at Second Maya Lithic Conference, San Antonio, Texas.

Palacio, J. 0.

1976 Archaeology in Belize. Cubola Productions, Belize.

Shafer, H. J.

1979 A Study of Two Maya Lithic Workshops at Colha, Belize. In The Colha Project, A Collection of Interim Papers, edited by T. R. Hester:18-27. Center for Archaeological Research, The University of Texas at San Antonio.

1982a A Preliminary Report of the Lithic Technology at Kichpanha, Northern Belize. In Archaeology at Colha, Belize, 1981 Interim Report, edited by T. R. Hester, H. J. Shafer, and J. D. Eaton:167-181. Center for Archaeological Research, The University of Texas at San Antonio and Centro Studi e Ricerche Ligabue, Venezia, San Antonio.

1982b Economic Considerations of Low 1 and Maya Chert Tool Industries. Paper presented at the 47th meeting of the Society for American Archaeology, Minneapolis.

1983 The Lithic Artifacts of the Pul1trouser Swamp Area: Settlements and Fields. In Pul1trouser Swamp: Ancient Maya Habitat, Agriculture and Settlement in Northern Belize, edited by B. L. Turner II and P. D. Harrison:212-245. University of Texas Press, Austin.

ms. Manuscript on Lithics from Operation 2011, 1980 Season. Manuscript on file with the Colha Project, Center for Archaeological Research, The University of Texas at San Antonio.

Shafer, H. J. and T. R. Hester

1983 Ancient Maya Chert Workshops in Northern Belize, Central America. American Antiquity 48(3):519-543.

1986 Maya Stone-Tool Craft Specialization and Production at Colha, Belize: Reply to Mallory. American Antiquity 51(1):158-166. 
Shafer, H. J. and F. M. Oglesby

1980 Test Excavations in a Colha Debitage Mound: Operation 4001. In The Colha Project: Second Season, 1980 Interim Report, edited by T. R. Hester, J. D. Eaton, and H. J. Shafer:195-220. Center for Archaeological Research. The University of Texas at San Antonio, and Centro Studi e Ricerche Ligabue, Venezia, San Antonio.

Shafer, H. J., T. R. Hester, T. C. Kelly, and N. Hammond

1980 An Analysis of Lithic Artifacts from 1976 Excavations at Cuel10, Belize. Manuscript on file at the Center for Archaeological Research. The University of Texas at San Antonio.

Thompson, J. E. S.

1939 Excavations at San Jose, British Honduras. Carnegie Institution of Washington Publication 506. 


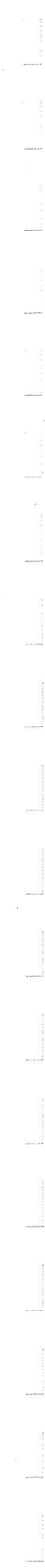

